\title{
Sexual behaviours and drug use among the street children
}

Shyam Lamsal

From $16^{\text {th }}$ International Symposium on HIV and Emerging Infectious Diseases

Marseille, France. 24-26 March 2010

\section{Background}

The aim of the study was to describe the HIV and STD risk behaviours among the street children.

\section{Methods}

This is a descriptive cross sectional study in which convenient sampling technique was adopted.

\section{Results}

Among the 100 conveniently chosen street children, 74 were Indians and 26 were Nepalese.

Ninety-one children were Hindu, 80 were above 12 years of age with the mean age and SD 14.74 $\pm 2.77,72$ had some education, 54 children at present worked as hawkers and servants at shops and 69 had a daily income between Rs. 30-90.

Forty-two subjects had sexual exposure at various age with either girlfriend or prostitute in which two subjects were homosexual. Seventy subjects were substance/s abusers, which included 49 alcohol abusers, 48 smokers, 42 tobacco chewers, 3 injectable drug abusers and 51 various other types of substance/s abusers. Majority of the children were uncertain about the amount and frequency of the substance/s they abuse except the tobacco chewers where majority i.e. 28 chew one or two packets of tobacco per week.

\section{Discussion}

It is concluded that the street children are in high risk for HIV and STD infection. The study was supported by various other studies conducted in Asia, Africa and Europe.

Published: 11 May 2010

Correspondence: shyamlamsal001@yahoo.com

B.P.Koirala Institute of Health Sciences, Dharan, Nepal

BHoMed Central @ 2010 Lamsal; licensee BioMed Central Ltd.
doi:10.1186/1742-4690-7-S1-P158

Cite this article as: Lamsal: Sexual behaviours and drug use among the street children. Retrovirology 2010 7(Suppl 1):P158.
Submit your next manuscript to BioMed Central and take full advantage of:

- Convenient online submission

- Thorough peer review

- No space constraints or color figure charges

- Immediate publication on acceptance

- Inclusion in PubMed, CAS, Scopus and Google Scholar

- Research which is freely available for redistribution

Submit your manuscript at www.biomedcentral.com/submit
C Biomed Central 